\title{
Production of Lactic Acid from Microalgal Biomass Chlorella vulgar ESP-31 as a feedstock using PVA Immobilized Bacteria L. Plantarum 23
}

\author{
Atika Nandini 1 *, Dilirani Nagarajan ${ }^{2}$, Jo-Shu Chang 2,3 \\ 1Department of Chemical Engineering, Universitas Pembangunan Nasional “Veteran” Surabaya, East Java, \\ Indonesia \\ 2Department of Chemical Engineering, National Cheng Kung University, Tainan, Taiwan \\ ${ }^{3}$ Research Center for Energy Technology and Strategy, National Cheng Kung University, Tainan, Taiwan
}

${ }^{*}$ Corresponding author:

E-mail:

atika.nandini.tk@upnjatim.ac.id

\begin{abstract}
Lactic acid is a valuable industrial chemical that is mostly used in the food and non-food industries such as the pharmaceutical industry. Production of lactic acid from renewable materials can be an alternative method to reduce the high production cost associated with raw material acquirement. In this study, polyvinyl alcohol (PVA) immobilized L. plantarum 23 was used. To obtain high lactic acid productivity and yield from renewable feedstock, the optimal fermentation conditions were determined in both batch and continuous mode. The renewable feedstock used was microalgal biomass Chlorella vulgaris ESP-31. The optimal conditions for this fermentation are $\mathrm{pH} 5.5$, temperature $30^{\circ} \mathrm{C}$, PVA particle loading $12.5 \%$, PVA concentration $5.25 \mathrm{~g}$ cell/L, HRT: 2-4 hrs, carbon source concentration $40 \mathrm{~g} / \mathrm{L}$. The feedstock was pretreated and hydrolyzed appropriately and the reducing sugars obtained were used. With microalgal sugars as a feedstock in continuous fermentation mode, the maximum lactic acid productivity of $12.59 \mathrm{~g} / \mathrm{L} / \mathrm{h}$ was achieved, compared to glucose $(7.39 \mathrm{~g} / \mathrm{L} / \mathrm{h})$. The highest yield achieved in this study $(0,98 \mathrm{~g} / \mathrm{g})$ was obtained when using pure glucose as the feedstock. Considering high productivity as the most important parameter, microalgal biomass seems to be the best feedstock for lactic acid production in continuous fermentation, giving high productivity and yield of $12.59 \mathrm{~g} / \mathrm{L} / \mathrm{h}$ and $0.91 \mathrm{~g} / \mathrm{g}$, respectively.
\end{abstract}

Keywords: L. plantarum 23, lactic acid fermentation, renewable feedstock, $C$. vulgaris ESP-31

\section{Introduction}

Lactic acid (LA) was one of the most important industrial products that were mostly used in many industries including cosmetic, food, chemical, and pharmaceutical industries. It is also used for the production of biodegradable plastics (PLA), which is a promising biocompatible and environmentally friendly alternative for fossil fuel-derived plastics. The demand for LA has been estimated to grow yearly at 5-8\% (Yadav, Chaudhari, \& Kothari, 2011). LA can be obtained by chemical synthesis or by microbial fermentation. Almost $90 \%$ of all LA production is achieved by microbial fermentation (Zhou et al., 2006). Despite that, the major challenge in LA production is the high primary production cost which is associated with the acquirement of raw materials, expensive nitrogen and carbon source, the downstream recovery and purification process.

The important parameters for efficient and economic LA production are higher production of LA and inexpensive raw material. To achieve high productivity and yield for LA production, two fermentation strategies (batch and continuous mode) were investigated. Although batch fermentation is the most used in LA production, it also has several disadvantages including low productivity due to long fermentation times and low cell concentrations. To solve this problem, another 
method such as continuous fermentation was investigated. However, these methods have some disadvantages and need to develop these processes to achieve efficient LA production. The fermentation using immobilization of microorganism in polymeric matrices have been reported to be efficient (Abdel-Rahman, Tashiro, \& Sonomoto, 2011). The continuous fermentation using PVA immobilization of cells can achieve high LA productivity and yield.

In addition to reducing the cost of raw materials, renewable feedstock was used as an alternative feedstock to produce LA. The demand for LA has increased considerably due to its wide range of applications, but the high cost of the raw materials which accounts for the highest portion of the production cost is known as one of the most serious problems for LA fermentation (Datta et al., 1995). Renewable feedstock such as microalgae biomass has been considered as a potential source because it has high sugar and carbohydrate content.

\section{Research Method \\ Bacterial strain and media}

The bacterial strain used in this study is L. plantarum 23. The condition of pre-culture for $L$. plantarum 23 at $30^{\circ} \mathrm{C}$. It was cultured in modified MRS (deMan, Rogosa and Sharpe) medium contains peptone, $10 \mathrm{~g} / \mathrm{L}$; beef extract, $10 \mathrm{~g} / \mathrm{L}$; Tween $80,1 \mathrm{~mL} / \mathrm{L}$; dipotassium phosphate, $2 \mathrm{~g} / \mathrm{L}$; sodium acetate, $5 \mathrm{~g} / \mathrm{L}$; ammonium citrate, $2 \mathrm{~g} / \mathrm{L}$; magnesium sulphate, $0.1 \mathrm{~g} / \mathrm{L}$; manganese sulphate, $0.05 \mathrm{~g} / \mathrm{L}$. The glucose concentration in the medium was varied according to the experimental requirements. For pre-culture, the L. plantarum 23 was cultured in $100 \mathrm{~mL}$ modified MRS medium with $20 \mathrm{~g} / \mathrm{L}$ glucose in a $500 \mathrm{~mL}$ flask at $30{ }^{\circ} \mathrm{C}$ with $200 \mathrm{rpm}$ agitation for $14 \mathrm{~h}$.

\section{Immobilization of bacterial cells}

L. plantarum 23 was cultured in $100 \mathrm{ml}$ modified MRS (Man, Rogosa, Sharpe) medium for 1214 hours. The fermentation broth was centrifuged at $10000 \mathrm{rpm}$ for 5 minutes at $25^{\circ} \mathrm{C}$. The supernatant was discarded, cells were washed once with sterile normal saline $(0.9 \% \mathrm{w} / \mathrm{v} \mathrm{NaCl})$, and resuspended in $20 \mathrm{ml}$ sterile normal saline. A $20 \mathrm{ml}$ of sterile normal saline with the cells was mixed with $80 \mathrm{ml}$ of $10.5 \%$ (w/v) polyvinyl alcohol. After thorough mixing, the immobilized cell beads were formed by dropping the mixture in a buffer solution composed of $0.1 \mathrm{M} \mathrm{Na} 2 \mathrm{HPO}_{4} \cdot 12 \mathrm{H}_{2} \mathrm{O}$, $0.4 \mathrm{M} \mathrm{NaH}_{2} \mathrm{PO}_{4} \cdot 2 \mathrm{H}_{2} \mathrm{O}$, and $1.13 \mathrm{M} \mathrm{H}_{3} \mathrm{BO}_{3}$ for 8 hours. The beads were rinsed using $4^{\circ} \mathrm{C}$ ice water and were stored in sterile ice-cold water for 2 days.

\section{Batch and continuous fermentation}

A bead of PVA immobilized L. plantarum 23 (with a cell concentration of $5.25 \mathrm{~g} / \mathrm{L}$ ) was reactivated in $200 \mathrm{ml}$ modified MRS medium containing $20 \mathrm{~g} / \mathrm{l}$ glucose in a $500 \mathrm{ml}$ flask at $200 \mathrm{rpm}$ and $30^{\circ} \mathrm{C}$ for $15 \mathrm{~h}$. The reactivated PVA immobilized beads were transferred to a $0.25 \mathrm{~L}$ reactor containing a fresh modified MRS medium with a glucose concentration of $40 \mathrm{~g} / \mathrm{L}$ to form the $0.2 \mathrm{~L}$ of final working volume. The PVA particle loading of $12.5 \%$ was used for the fermentation. Argon was used to replace the air in the fermenter and $1 \mathrm{ml}$ of L-cysteine $\mathrm{HCl}(100 \mathrm{~g} / \mathrm{l})$ was added into the medium. The fermentation was conducted under anaerobic conditions at $30^{\circ} \mathrm{C}, \mathrm{pH} 5.5$, and $200 \mathrm{rpm}$.

The continuous fermentation was initiated as a batch culture with an initial glucose concentration of $40 \mathrm{~g} / \mathrm{L}$. The conditions of fermentation were at $30^{\circ} \mathrm{C}, \mathrm{pH} 5.5,200 \mathrm{rpm}$ agitation, and anaerobic condition. The culture conditions were maintained at a pH of 5.5 by $5 \mathrm{~N} \mathrm{NaOH}$ solutions. The fresh nutrition modified MRS medium including $40 \mathrm{~g} / \mathrm{l}$ glucose and $0.5 \mathrm{~g} / \mathrm{L} \mathrm{L-cysteine} \mathrm{HCl}$ was fed into the reactor after the batch mode of $14 \mathrm{hrs}$. The varying HRT (hydraulic retention time) of 4 , 3 , and 2 hrs were used in this fermentation. To carry out the LA production from renewable materials as a feedstock, the glucose concentration of $40 \mathrm{~g} / \mathrm{L}$ as a carbon source was replaced by microalgal hydrolysate. 


\section{Renewable feedstock (Chlorella vulgaris ESP-31)}

Microalgae (Chlorella vulgaris ESP-31) biomass was consist of carbohydrate, 46.88\%; protein, $13 \%$; lipid, $20.55 \%$ and ash, $12.11 \%$ (on a dry weight basis). The dry microalgae biomass needs to be hydrolyzed to release the simple sugar component. The acid pretreatment was used for hydrolysis of the algal biomass (sulfuric acid $4 \%, 120^{\circ} \mathrm{C}, 29 \mathrm{~min}$ ). The hydrolysate was neutralized with calcium carbonate, centrifuged, filtered and the composition was analyzed. The total reducing sugar concentration was $25.8 \mathrm{~g} / \mathrm{L}$ (glucose, $21.76 \mathrm{~g} / \mathrm{L}$; xylose, $2.66 \mathrm{~g} / \mathrm{L}$ and arabinose, $1.38 \mathrm{~g} / \mathrm{L}$ ). A $0.56 \mathrm{~g} / \mathrm{L}$ of HMF and $0.12 \mathrm{~g} / \mathrm{L}$ of furfural were present in very low concentration as fermentation inhibitors.

\section{Analytical methods}

The biomass concentration of L. plantarum 23 was determined by the absorbance wavelength at $600 \mathrm{~nm}$ using UV/Vis spectrophotometer (Model U-2001, Hitachi, Japan). The concentration of sugar, lactic acid and other by-products (acetic acid, ethanol) were determined by HPLC equipped with ICSep ICE-COREGEL 87H3 Column and refractive index detector (RID). The mobile phase used was $0.008 \mathrm{~N} \mathrm{H} 2 \mathrm{SO} 4$ at the flow rate of $0.4 \mathrm{~mL} / \mathrm{min}$. The column temperature was maintained at $70{ }^{\circ} \mathrm{C}$ and the injection volume was $20 \mu \mathrm{L}$. The concentration of sugar, lactic acid, and by-products (acetic acid, ethanol) were calculated from the standard calibration curve.

\section{Results and Discussion}

\section{LA production using pure glucose as a carbon source}

As shown in Figure 1(a), LA concentration, yield, and productivity from batch fermentation using PVA immobilized L. plantarum 23 were $34.81 \mathrm{~g} / \mathrm{L}, 0.87 \mathrm{~g} / \mathrm{g}$, and $3.48 \mathrm{~g} / \mathrm{L} / \mathrm{h}$, respectively. A $3.73 \mathrm{~g} / \mathrm{L}$ of acetic acid was produced as a by-product during batch fermentation.

Compared to batch fermentation, Figure 1(b) shows in continuous fermentation can achieve a maximum lactate concentration of $29.56 \mathrm{~g} / \mathrm{L}$ with yield and productivity of $0.98 \mathrm{~g} / \mathrm{g}$ and 7.39 $\mathrm{g} / \mathrm{L} / \mathrm{h}$, respectively. Continuous LA fermentation is attractive in terms of overcoming the by-product inhibition that occurs in batch fermentation by diluting the product in the fermentation broth with fresh medium (Wee \& Ryu, 2009). Considering productivity, yield and production, continuous fermentation is more effective compared to batch fermentation, with high productivity and yield.

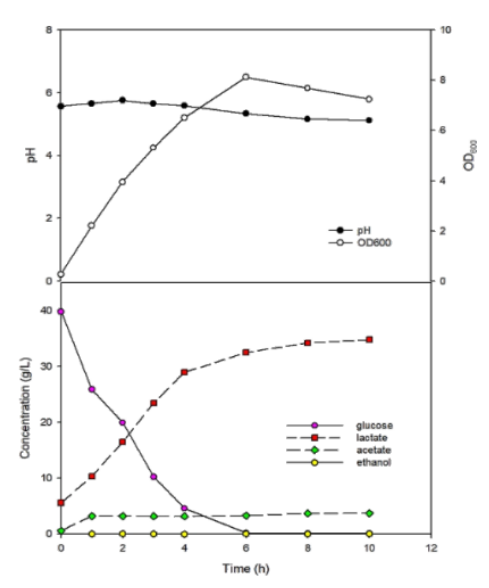

A

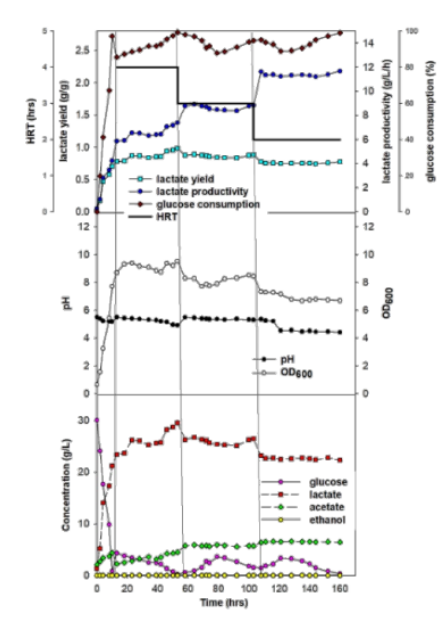

B

Figure 1. Lactic acid fermentation using glucose as the carbon source with immobilized cell (a) batch fermentation, (b) continuous fermentation 


\section{LA production using microalgae biomass as a feedstock}

The microalgae biomass of Chlorella vulgaris ESP-31as a feedstock for LA production and the result shown in Fig. 2. The initial sugar concentration after microalgae hydrolysate mixed with modified MRS medium was $46.88 \mathrm{~g} / \mathrm{L}$ (glucose, $40.35 \mathrm{~g} / \mathrm{L}$; xylose, $3.66 \mathrm{~g} / \mathrm{L}$, and arabinose, $2.87 \mathrm{~g} / \mathrm{L}$ ). In batch fermentation, LA concentration of $40.30 \mathrm{~g} / \mathrm{L}$ was attained with a maximum productivity of $6.72 \mathrm{~g} / \mathrm{L} /$ $\mathrm{h}$ and a yield of $0.97 \mathrm{~g} / \mathrm{g}$ (Figure. 2(a)). The hexose (glucose) was utilized first to produce LA. After glucose was completely consumed, bacteria consumed xylose and arabinose, and convert it to LA. Acetic acid concentration as a by-product increased to $5.55 \mathrm{~g} / \mathrm{L}$ due to the metabolism of pentose. Figure 2(b) showed the performance of continuous LA production. the performance of continuous LA production. A maximum lactate concentration of $40.58 \mathrm{~g} / \mathrm{L}$ was achieved with a high yield of $0.98 \mathrm{~g} / \mathrm{g}$ when using reducing sugar concentration of $40 \mathrm{~g} / \mathrm{L}$ with PVA immobilized cell and HRT of 4 hours. The highest productivity of $16.17 \mathrm{~g} / \mathrm{L} / \mathrm{h}$ was obtained in HRT 2 hours. A higher acetic concentration of $5.63 \mathrm{~g} / \mathrm{L}$ was produced during fermentation in HRT 2 hours as a by-product. Lactate concentration of $37.76 \mathrm{~g} / \mathrm{L}$ was achieved with yield and productivity of $0.91 \mathrm{~g} / \mathrm{g}$ and 12.59 $\mathrm{g} / \mathrm{L} / \mathrm{h}$ when using reducing sugar concentration of $40 \mathrm{~g} / \mathrm{L}$ with PVA immobilized cell and HRT of 3 hours. The inhibitor (acetic) concentration of $5.53 \mathrm{~g} / \mathrm{L}$ was produced during this fermentation as a by-product.

Table 1 showed that using continuous fermentation was better than using batch fermentation. Considering the yield, productivity and LA production, continuous fermentation using HRT 3 hours seem to be the optimal condition compared to the HRT 4 and 2 hours. Microalgae are typically rich in proteins, and the biomass used in this fermentation has a protein content of $13 \%$. Also, microalgae are a natural source of vitamins, minerals, and other essential nutrients. When microalgal hydrolysate was used as a carbon source, the organic nitrogen content of the medium increased from $6.12 \mathrm{~g} / \mathrm{L}$ (glucose-MRS medium) to $8.52 \mathrm{~g} / \mathrm{L}$. Amino acid analysis indicated that the predominant amino acids present in the hydrolysate were serine, methionine, histidine, glutamic acid, aspartic acid, cysteine, phenylalanine, and tryptophan. Of these, glutamic acid, histidine, serine, and aspartic acid were preferentially utilized by L. plantarum 23.
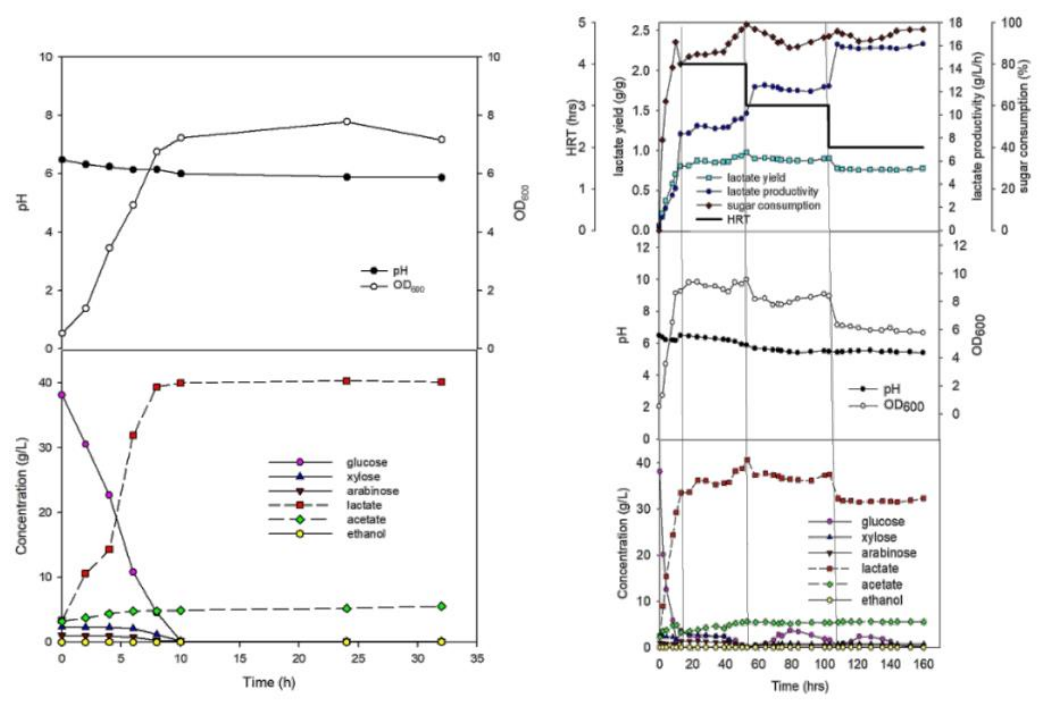

Figure 2. Lactic acid fermentation using microalgae hydrolysate as the carbon source with immobilized cell (a)batch fermentation, (b) continuous fermentation 
Table 1. LA production using different fermentation strategies using microalga hydrolysate as a feedstock

\begin{tabular}{cccccc}
\hline $\begin{array}{c}\text { Fermentation } \\
\text { mode }\end{array}$ & $\begin{array}{c}\text { LA } \\
\text { concentration } \\
(\mathbf{g} / \mathbf{L})\end{array}$ & $\begin{array}{c}\text { LA } \\
\text { yield } \\
\mathbf{( g / g )}\end{array}$ & $\begin{array}{c}\text { LA } \\
\text { productivity } \\
(\mathbf{g} / \mathbf{L} / \mathbf{h})\end{array}$ & $\begin{array}{c}\text { Sugar } \\
\text { consumption } \\
\mathbf{( \% )}\end{array}$ & $\begin{array}{c}\text { Acetate } \\
\text { concentration } \\
\mathbf{( g / L )}\end{array}$ \\
\hline Batch & 40.30 & 0.97 & 6.72 & 99.11 & 5.55 \\
\hline Continuous & & & & & \\
\hline HRT 4 hrs & 40.58 & 0.98 & 10.15 & 99.22 & 5.6 \\
\hline HRT 3 hrs & 37.76 & 0.91 & 12.59 & 96.90 & 5.53 \\
\hline HRT 2 hrs & 32.33 & 0.78 & 16.17 & 96.80 & 5.63 \\
\hline
\end{tabular}

\section{Conclusion}

Increasing LA productivity by using PVA immobilized L.plantarum 23 and microalgae biomass as a renewable feedstock was determined. Microalgal biomass seems to be a promising low-cost feedstock for lactic acid production on continuous fermentation mode, giving high productivity and yield obtained of $12.59 \mathrm{~g} / \mathrm{L} / \mathrm{h}$ and $0.91 \mathrm{~g} / \mathrm{g}$, respectively. The microalgal biomass ( $C$. vulgaris ESP-31) has high sugar content (glucose, xylose, and arabinose) and also rich in other essential nutrients like proteins, vitamins, and minerals. So it can simultaneously provide carbon source and nitrogen source. This leads to marked enhancement in lactic acid production.

\section{Acknowledgment}

This research was conducted in Energy/Environmental Biotechnology \& Biochemical Engineering Laboratory (EEBBE laboratory) by Prof. Jo-Shu Chang at National Cheng Kung University, Taiwan.

\section{References}

Abdel-Rahman, M. A., Tashiro, Y., \& Sonomoto, K. (2011). Lactic acid production from lignocellulose-derived sugars using lactic acid bacteria: Overview and limits. Journal of Biotechnology, 156(4), 286-301

Datta, R., Tsai, S.-P., Bonsignore, P., Moon, S.-H., \& Frank, J. R. (1995). Technological and economic potential of poly (lactic acid) and lactic acid derivatives. FEMS Microbiology Reviews, 16(2-3), 221-231.

Wee, Y. J., \& Ryu, H. W. (2009). Lactic acid production by Lactobacillus sp. RKY2 in a cell-recycle continuous fermentation using lignocellulosic hydrolyzates as inexpensive raw materials. Bioresource Technology, 100(18), 4262-4270.

Yadav, A. K., Chaudhari, A. B., \& Kothari, R. M. (2011). Bioconversion of renewable resources into lactic acid: an industrial view. Critical Reviews in Biotechnology, 31(1), 1-19.

Zhou, S., Shanmugam, K. T., Yomano, L. P., Grabar, T. B., \& Ingram, L. O. (2006). Fermentation of $12 \%$ (w/v) glucose to 1.2 M lactate by Escherichia coli strain SZ194 using mineral salts medium. Biotechnology Letters, 28(9), 663-670. 